\title{
Kognitiivisesta kurssididaktiikasta kehittävään työntutkimukseen
}

\begin{abstract}
Miettinen, Reijo 1985. Kognitiivisesta kurssididaktiikasta kehittävään työntutkimukseen. Aikuiskasvatus, 5, 4, 147-155. - Artikkelissa analysoidaan Valtion koulutuskeskuksessa tapahtunutta henkilöstökouluttajien koulutusohjelman sisällöllistä kehitystä. Kehitys on tapahtunut erillisistä lyhytkursseista, kognitiivisen kurssididaktiikan kautta työn teoreeitiseen tarkasteluun. Koulutustoiminnan lähtökohdiksi ovat tulossa uusi työn käsite ja kehittävä työntutkimus.
\end{abstract}

Vuonna 1980 käynnistyi Valtion koulutuskeskuksessa valtion henkilöstökouluttajien jatkokoulutusohjelma. Tämän koulutusohjelman valmistelu ja toteuttaminen kehittyi samalla pedagogisen ja työelämän aikuiskoulutusta koskevan uudistustyön foorumiksi. Tässä Aikuiskasvatuslehden numerossa esitelty kehittävän työntutkimuksen malli on eräiltä osin muotoutunut koulutusohjelman kehittämistyőssä. Tarkoituksenani on analysoida, minkälaisen sisällöllisen kehityksen ja minkälaisten koulutukseen liittyvien ongelmien ratkaisemisen kautta kehitys johti kehittävän tyőntutkimuksen lähestymistavan muotoutumiseen. Siksi keskityn koulutusohjelman sisällön kehitykseen enkä tarkastele systemaattisesti koulutusohjelman toteuttamista ja tuloksia.

Jatkokoulutusohjelman luonnetta uusia pedagogisia ratkaisuja ja teoreettisia malleja kehittävänä hankkeena kuvaa se, että vuosien 1980 ja 1984 välillä koulutusohjelmaan liittyen on tuotettu 12 julkaisua, joista suurin osa on ilmestynyt Valtion koulutuskeskuksen julkaisusarjassa. Koska julkaisuissa on noudatettu tieteellisten julkaisujen dokumentointikäytäntöä, on ohjelmaan liittyvä sisällöllinen kehitys kenen tahansa analysoitavissa. Artikkelin lähdeluettelossa on erikseen esitetty nämä koulutusohjelmaan liittyvä julkaisut, jotka ovat samalla toimineet ohjelman oppimateriaaleina. $\mathrm{Ne}$ ovat samalla osoitus siitä, että käytännön koulutuksen ongelmien ratkaiseminen ei ainoastaan mahdollista vaan myös edellyttää teoreettistạ työtä ja tätä kautta uusien välineiden ja toimintamallien kehittämistä.

\section{Henkilöstökouluttajien jatkokoulutusohjelman synty}

Jatkokoulutusohjelman ja siihen liittyvän kehittämistyön taustalla ovat valtionhallinnon henkilöstökoulutuksessa tapahtuneet muutokset 1970-luvulla. Henkilöstökoulutuksen măărä valtion virastoissa kasvoi nelinkertaiseksi vuosien 1972 ja 1978 välillä. Koulutus laajeni ennen muuta ministerioissä ja keskusvirastoissa. Aikaisemmin henkilöstőkoulutuksen painopiste oli työvirastojen ammatillisessa koulutuksessa. Nyt hallintovirastoihin perustettiin koulutusyksikkőjä, joihin palkattiin päätoimisia koulutuspäällikőitä ja koulutussuunnittelijoita. Näillä "yleiskouluttajilla" oli yleensä hallinnollis-yhteiskuntatieteellinen tai humanistinen peruskoulutus ja vain harvoin pedagogista koulutusta. 1970-luvulla muotoutui koulutuskäytäntö, jota voidaan luonnehtia "pirstoutuneeksi kurssituotannoksi"'. Koulutus koostui suuresta määrästä toisiinsa liittymättőmiä lyhytkursseja, joiden organisoinnista yleiskoulutushenkilöstő vastasi. Koulutustoiminnan vălineet saatiin pääosin VKK:n kouluttajakursseilta ja tietyistä koulutusoppaista, joiden sisältönä oli koulutusteknologinen ajattelutapa ja suunnittelumalli (Miettinen 1984b, käynnisti v. 1977 valtion henkilöstőkouluttajien ammattikuvatutkimuksen (Launos \& Peisa, 1979). Sen keskeisenä johtopäätöksenä oli, että henkilöstökouluttajan ammatti oli vasta muotoutumassa ja että koulutushenkilöstöltä 
puuttui lähes kokonaan yhtenäinen pedagoginen tietopohja.

Kouluttajien ammattikuvaselvityksen pohjalta käynnistettiin henkilöstökouluttajien jatkokoulutusohjelman valmistelu, jonka tuloksena vuonna 1980 julkaistiin koulutusohjelman varsin perusteellinen opetussuunnitelma (Valtion... 1980) ja käynnistettiin itse ohjelma. Jatkokoulutusohjelman opetussuunnitelmassa arvioitiin koulutustyön kehittämistarpeita seuraavasti: 1970-luvun pirstoutunut kurssitoiminta on johtanut koulutuksen didaktisesti heikkoon tasoon ja hallinnon kehittämisen kannalta pinnalliseen ja pirstoutuneeseen erillistietojen ja valmiuksien jakamiseen. Koulutus ei tưota syvällistä näkemystä eikä kunnollista ammattipätevyyttä. Näinollen koulutusohjelman tavoitteena oli valtion henkilöstökoulutuksen muuttaminen koulutettavien ammatillista pätevyyttä syvällisemmin kehittäväksi. Tämä edellytti pitempien koulutusohjelmakokonaisuuksien luomista (Valtion 1980, s. 8-10). Vastaavasti oli henkilöstökouluttajien työ nostettava ammatilliselle tasolle. Tämä ammatillistaminen katsottiin voitavan saavuttaa turvaamalla yhtenäispätevyys, pätevyyden tieteellinen perusta sekä pätevyyden virallinen tunnustaminen hallintosäädöksin (mts.

Koulutusohjelman taustana oleva käsitys pätevyydestä perustui siis varsin selkeästi malliin tiedeperusteisesta professioammatista. Tällainen ammatillinen pätevyys pyrittiin turvaamaan kaksi ja puoli vuotta kestävällä koulutusohjelmalla, joka koostui neljästä oppiaineesta: hallintotiede ja organisaatioteoriat, tyőtieteet (työn sosiologia ja työpsykologia), koulutuksen sosiologia ja koulutussuunnittelu sekă neljänneksi didaktiikka. Kustakin oppiaineesta järjestettiin joukko kurssi- ja seminaarijaksoja niihin liittyvine välitehtävineen. Koulutushenkiloiden ammatillisen tason kohottamista pidettiin ensi askeleena koko koulutustyön tason kohottamisessa.

Sisällollisesti kurssi merkitsi siirtymää opetusteknologisesta (ja behavioristisesta) koulutuskäytännőstä ja -ajattelusta laajempaan oppimis- ja didaktisten teorioiden analysointiin. Kehittämistyön sisältönä oli arvioida eri oppimisteorioita ja löytää niiden pohjalta kehittyneimmät mahdolliset välineet koulutustyölle. Tämän teoreettisen ja käytännöllisen arvioinnin tuloksia on esitelty useissa Valtion koulutuskeskuksen julkaisuissa (Engeström 1984, Miettinen 1984a ja 1984b, Virkkunen 1983). Kehittyneimmiksi ja lupaavimmiksi tässä arvioinnissa osoittautuivat ns. kognitiiviset oppi- misteoriat. Niiden pohjalta kehitettiin välineitä, joilla oppimisen "sisäiset"' tekijät ts. oppilaiden ajattelu, toimintaa ohjaavat tietorakenteet ja mallit voitaisiin systemaattisesti ottaa huomioon opetuksen suunnittelussa. Koulutusohjelman kehitys sisälsi oppimisteorioiden jatkuvaa arviointia, siirtymiä ja uusien opetuksen suunnittelun keinojen luomista. Juuri tähän kehitykseen seuraavassa paneudutaan.

Kehittävän työntutkimuksen lähestymistavan muotoutumisen perustana oli kaksi ratkaisevaa teoreettista "siirtymää". Toinen oli siirtymä oppimiskäsitteessä kognitivistisesta tietorakenteen tai älyllisen teon muotoutumisen teoriasta kulttuurihistorialliseen käsitykseen tietoisesta oppimistoiminnasta. Toinen oli siirtymä tehtävä- ja ammattikeskeisestä työkäsitteestä työn mieltämiseen kehittyvänä yhteiskunnallisena järjestelmänä (Toikka 1984). Nämä toteutuivat koulutusohjelman sisällä vähitellen. Siirtymän kuvaamiseksi kehitys koulutusohjelman sisällössä on seuraavassa jaettu kahteen vaiheeseen. Ensimmäinen on kognitiivisen kurssididaktiikan vaihe vuosina 1980-1981. Toinen on kehittävän työntutkimuksen lähestymistavan muotoutumisen vaihe vuosina 1982-1984. Ensin on siis tarkasteltava kognitiivisen kurssididaktiikan peruskäsitteitä, sitä vastaavaa koulutuksen suunnittelukäytäntőä sekä sitä, mitä koulutuskäytännơn ongelmia kognitiivinen kurssididaktiikka ei pystynyt ratkaisemaan.

\section{Kognitiivisen kurssididaktiikan peruskäsitteet}

Koulutusohjelman ydinsisältönä oli vuodesta 1978 kehitelty "'Työelämän aikuiskoulutuksen didaktisen teorian kurssi', joka pidettiin Valtion koulutuskeskuksessa ensimmäisen kerran v. 1979. Tämän kurssin tavoitteena oli arvioida kriittisesti didaktisia teorioita ja tarjota kognitiiviseen oppimisnäkemykseen perustuvat välineet kurssin tai ylipäänsä rajatun opetuskokonaisuuden suunnittelulle. Kurssin ydinsisältő 80-luvun alussa kiteytyi kolmeen käsitepariin: sisällöllinen oppimismotivaatio ja ristiriita, tiedolliset rakenteet ja orientaatioperusta sekä täydellinen oppimisprosessi ja didaktinen kokonaiskäsittely. Nämä käsitteet kuvattiin kurssilla vuodesta 1980 kuviossa 1 esitetyn mallin avulla. 
Kuvio 1. Kognitiivisen kurssididaktiikan peruskäsitteet

\section{TULOKSEKAS OPPIMINEN}

\begin{tabular}{|c|c|c|}
\hline $\begin{array}{l}\text { SISÄLLÖL- } \\
\text { LINEN } \\
\text { OPPIMIS- } \\
\text { MOTIVAA- } \\
\text { TIO }\end{array}$ & $\begin{array}{l}\text { TIEDOL- } \\
\text { LISET } \\
\text { RAKENTEET } \\
\text { PERIAAT- } \\
\text { TEET } \\
\end{array}$ & $\begin{array}{l}\text { TÄYDELLI- } \\
\text { NEN OPPI- } \\
\text { MIS- } \\
\text { PROSESSI }\end{array}$ \\
\hline $\begin{array}{l}\text { TIEDOL- } \\
\text { LISET } \\
\text { RISTI- } \\
\text { RIIDAT }\end{array}$ & $\begin{array}{l}\text { ORIENTAA- } \\
\text { TIO- } \\
\text { PERUSTA }\end{array}$ & $\begin{array}{l}\text { DIDAKTI- } \\
\text { NEN KOKO- } \\
\text { NAIS- } \\
\text { KÄSITTELY }\end{array}$ \\
\hline
\end{tabular}

HYVÄ OPETUS

Tarkasteltakoon kutakin edellä esitetyistä käsitteistä. Oppimismotivaatiota koskevassa ajattelussa ensisijaiseksi asetettiin sisällöllisen, tietoisen oppimismotivaation aikaansaaminen (itse sisältöön ja sen käyttömahdollisuuksiin kohdistuva). Tällainen motivaatio viriää sen kautta, että oppilas tiedostaa ristiriidan nykyisen ajattelu- ja suoritustapansa ja hänelle asetetun tehtävän tai vaatimuksen välillä. Tämän ristiriidan tulee olla oppilaiden työn tai elämän kannalta objektiivisesti merkittävä. Opetuksessa ristiriita voidaan tehdä tietoiseksi tehtävän avulla. Tässä vaiheessa käsitys ristiriidoista oli hyvin avoin. Opetuksessa esitettiin esimerkkejä erilaisista ristiriidoista, niin toiminnallisista kuin tiedollisistakin. Vaikka käsitys ristiriidoista oli alusta asti moniaineksinen, kiteytyi se opetuksessa ja oppimateriaaleissa tiedolliseksi ristiriidaksi, ristiriidaksi oppilaan aikaisemman tietorakenteen ja uuden oppiaineksen välillä.

Toinen kognitiivisen kurssididaktiikan peruskäsitteistä liittyy oppimistavoitteeseen ja opetussisältöön. Tätä käsitettä työstettäessä lähtökohtina olivat 1960-luvun amerikkalaisen kognitiivisen psykologian suurten edustajien Jerome Brunerin ja David Ausubelin teoriat ja toisaalta P.J. Galperinin teoria orientoitumisesta ja orientaatioperustan käytöstä henkisen teon suunnitelmallisessa muodostamisessa. Brunerin ja Ausubelin näkemyksillä kognitiivisten rakenteiden ja periaatteiden merkityksestä oppimiselle oli keskeinen merkitys (Bruner 1960 ja 1966, Ausubel \& al. 1978). Erityisesti Ausubelin käsityksellä mielekkäästä oppimisesta uuden oppiaineksen liittämisenä aikaisempaan kognitiiviseen rakenteeseen ja ennakkojäsentäjien käytöstä opetuksessa tämän liittämisprosessin edistämiseksi oli tärkeä sija kurssin opetussisällössä. Käytännön apuvälineeksi opetuksen sisällöllisen tavoitteen määrittelemiseksi omaksuttiin Galperinin orientaatioperusta (laadittavan esineellisen mallin mielessä), jota kutsuttiin myös selitys- ja toimintamalliksi. Galperinin teoria toi käsitteeseen toiminnallisuuden aspektin: orientaatioperustaa käyttämällä pyrittiin sisäistämään ja sen käyttöön ongelmien ratkaisemisessa.

Myös opetuksen sisällön käsittelyssä kurssin anti oli moniaineksinen ja ristiriitainen. Brunerin ja Ausubelin teoriat koskevat lähinnä kouluoppimista, ts. käytännön toiminnasta ja työstä irroitettua oppiaineksen omaksumisen, muokkaamisen ja tietorakenteiksi työstämisen prosessia. Siksi niihin liittyy intellektualismin rasite. Ne eivät tarkastele tietorakenteiden aktiivista käyttämistä todellisessa toiminnassa. Tätä tietorakenteiden psykologiaa täydensi Galperinin teoria, joka puolestaan rajoittui yksittäisten tekojen tai rajattujen suoritusten oppimiseen. Toinen oleellinen lisä tietorakenteiden psykologiaan oli V. Davydoviin nojautuva tarkastelu empiirisen arkiajattelun ja teoreettisen ajattelun laadullisista eroista. Kun tavoitteiksi oli asetettu mahdollisimman korkeatasoiset kognitiiviset rakenteet, oli selvä, että teoreettisilla käsitteillä oli keskeinen merkitys yritettäessä muodostaa tällaisia rakenteita. Tätä ajatusta kehitettiin siten, että orientaatioperustan sisällön muodostamisen didaktisesti "'ideaaliksi"' asetettiin teoreettinen käsite," alkuperäinen toiminnallinen perussuhde, periaate tai alkusolu."

Orientaatioperustan käyttö kurssiin tavoitteenasettelun välineenä osoitti, että orientaatioperusta ymmärrettiin pääasiassa kurssin oppiaineksen jäsentämisen ja pelkistämisen välineeksi ts. Ausubelin tarkoittamaksi ennakkojäsentäjäksi. Orientoitumisessa ja orientaatioperustan määreistä olennaisen esiin nostaminen jäi hallitsevaksi, vaikka orientaatioperustojen käytön merkitystä korostettiinkin.

Kolmas peruskäsite oli täydellinen oppimisprosessi ja didaktinen kokonaiskäsittely. Täydellisellä oppimisprosessilla ymmärrettiin itsenäisen hallinnan asteelle edennyttä oppimista. Se määriteltiin siten, että ollakseen täydellinen oppimisprosessiin oli sisällyttävä kuusi oppimisprosessin osatekijää, jotka olivat motivoituminen, orientoituminen, sisäistäminen, ulkoistaminen l. käyttö, arviointi sekä oman oppimisen kontrolli. Näiden (luettelona esitettyjen) osatekijöihin "'kattamiseen"' pyrittiin didaktisen kokonaiskäsittelyn avulla. Tämä $F$. Herbartin alunperin esittämä metodinen idea sisältää ajatuksen, että oppiaines voidaan 
opettaa oppilaiden oppimisen kannalta optimaalisella tavalla. Opetuksen kullekin vaiheelle hahmotettiin opetuksellinen tehtävä, ts. tehtävä oppimisprosessin kannalta. Tämän idean toteuttamiseksi (jolla nyt oli Hebartin oppimiskäsityksestä, assosiaatiopsykologiasta täysin poikkeava psykologinen perusta) luotiin uusi käytännöllinen työväline, opetuksen suunnittelun lomake. Siinä opetuksen etenemistä suunniteltiin yhtä aikaisesti neljän tekijän suhteen: 1) aika, 2) sisältö, 3) oppilaiden oppiminen (opetuksellinen tehtävä) sekä 4) opetuksen toteuttamistavat (opetusmenetelmät ja ryhmittyminen). Lomake osoittautui erittäin hyödylliseksi työvälineeksi. Mainitun neljän tekijän keskinäinen optimointi ilman tällaista välinettä (pelkästään päässä) on mahdotonta. Uusi väline mahdollisti opetuksen kollektiivisen suunnittelun ja sen avulla kouluttajat joutuivat ajattelemaan opetusta oppilaiden oppimisen kannalta ja suhteuttamaan sisällön, opetukselliset tehtävät ja opetusmenetelmät toisiinsa. Didaktisen kokonaiskäsittelyn käsite ja sille rakennettu väline merkitsi olennaista edistysaskelta opetuksen didaktisessa suunnittelussa ja laadussa. Edellä sanotusta huolimatta uusi väline on sidoksissa teoriahistoriaansa. Didaktinen kokonaiskäsittely on edelleen oppiaineksen opetuksellisen käsittelyn menetelmä, jossa esittävän opetuksen eri muotoihin liitetään harjoittelua ja soveltamistehtäviä.

Kognitiivisen kurssididaktiikan sisällössä oli alusta asti aineksia sekä 1960-luvun amerikkalaisesta kognitiivisesta psykologiasta että kulttuurihistoriallisesta toiminnan teoriasta. Tietorakenteiden psykologian näkökulma, oppijan ja oppiaineksen välinen suhde ja kognitiivisten rakenteiden muodostaminen olivat tässä kokonaisuudessa hallitsevassa asemassa. Mistä tämä johtui?

Ensinnäkin voidaan sanoa, että opetussisältöä kehitettiin kurssin tai opetuskokonaisuuden suunnittelua varten ts. tietoisesti kurssididaktiikan kehittämiseksi. Tämä lähtökohta asetti rajoja luokkahuoneen seinät ylittävän oppimiskäsityksen omaksumiselle ja kehittelylle. Toinen ja merkittävä syy liittyy työn $k \ddot{a}$ sitteeseen. Henkilöstökoulutukselle tyypillisen kurssin taustalla on käsitys pätevyydestä erillistaitojen ja valmiuksien tuottamisena. Niin kauan kuin oppimisen kohteena on yksittäinen teko tai ongelma, teoreettinen malli tai käsite työtoiminnan välineenä ei yleensä ole tarpeen. Koulutusohjelman taustalla taas oli ihanne tiedeperustaisesta ammattipätevyydestä. Tietorakenteiden psykologian konseptio tieteenalan tai oppialan tiedon jäsentyneestä omaksumisesta käy yksiin tämän ammattipainotteisen pätevyyskäsityksen kanssa, mutta soveltuu väkinäisesti kurssikeskeiseen koulutusajatteluun. Niin kauan kun työelämässä oppimisen kohdetta ei voitu jäsentää kehittyväksi kokonaisjärjestelmäksi (vaan suoritukseksi tai yksilön tehtäväkokonaisuudeksi) ajatus teoreettisten mallien tärkeydestä oppimisen ja työn kehittämisen välineenä ei tullut ymmärrettäväksi eikä alkanut elää osallistujien ajattelun ja käytännön työn välineenä. Ennenkuin siirtymä tietorakenteiden psykologiasta tietoisen oppimistoiminnan käsitteen kehittämiseen ja omaksumiseen tuli mahdolliseksi, tarvittiin sekä kurssimuodon että perinteisen työ- ja pätevyyskäsityksen muuttumista.

\section{Koulutustarpeiden määrittely}

Kurssididaktiikan rinnalla koulutusohjelman koulutussuunnittelu-oppiaineessa pohdittiin koulutustavoitteiden määrittelyä. 1970-luvulla virastoissa oli alettu laatia kattavia koulutuksen KTS-suunnitelmia, joiden pohjaksi koulutustarpeita pyrittiin kartoittamaan. Käytännössä tämä tapahtui kyselemällä eri henkilöryhmiltä, mitä koulutusta he haluavat sekä johtamalla koulutustehtäviä viraston toimintasuunnitelmista. Jatkokoulutusohjelman alussa suunnittelun pohjaksi hahmoteltiin kahdenlaisia analyyseja: organisaatioanalyysia ja ammattianalyysia.

Näistä "ammattien kokonaisvaltaisella ja tavoitteellisella kehittämisellä" oli keskeinen sija. Ongelmana oikeastaan oli, että 1970-luvun ammattikuvatutkimus ei tarjonnut käytännön välineitä kehittämistarpeiden esiin saamiselle. Usein työläs, erillinen selvitystyö tuotti fakta-aineistoa, mutta ei näkemystä ammatillisen toiminnan tulevasta kehityksestä ja haasteista (tästä hyvänä esimerkkinä on mainittu henkilöstökouluttajien ammattikuvatutkimus). Tämä johtui epäilemättä siitä, että kehitys tulee näkyviin hyödyllisiä lopputuloksia tuottavan kokonaistoiminnan analysoinnissa, mutta ei kokonaisuudesta irroitetun erillisen henkilöryhmän tehtävien tarkastelussa.

Toinen tarpeen analysointitapa olivat erilaiset organisaatioanalyysit. Organisation kehittämistoiminnan (OD) piirissä kehitetyt menetelmät keskittyivät koettujen ongelmien ja sosiaalisten ristiriitojen jäljittämiseen. Hallinto- 
teorian piiristä yritettiin soveltaa organisaation tehtävä- ja funktioanalyysejä. Myöskään nämä menetelmät eivät tuntuneet tuottavan koulutuksessa käyttökelpoisia tuloksia. Erilaisia kehittämisen tarpeita saatettiin saada esille, mutta ei kyetty miten ja minkälaisten sisältöjen ja välineiden avulla kehittämistehtäviin olisi voitu käydä käsiksi.

Oppiaineiden jakamisella koulutussuunnitteluun ja didaktiikkaan (opetuksen suunnittelu) toistettiin erottelu, joka oli jo tapahtunut käytännössä: koulutustarpeiden analysointi ja koulutuksen taloudellis-hallinnollinen suunnittelu oli eronnut opetuksen sisältöjen suunnittelusta. Opetuksesta erillinen tarveanalyysi liitettiin hallinnolliseen KTS-suunnitteluun. Tämä aiheutti sinänsä käsitteellistä hämmennystä.

Kun organisaation tarpeiden ja ammattien tarpeiden analyysit vielä eriytettiin toisistaan, kokonaiskuva oli varsin sekava.

\section{Mitä ongelmia kognitiivisen kurssididaktiikka ja -suunnittelu ei pystynyt ratkaisemaan?}

Kognitiivinen kurssididaktiikka oli rakennettu parantamaan opetuksen laatua. Tämän tehtävän suorittamiseksi se antoikin oleellisesti opetusteknologista perinnettä kehittyneempiä välineitä. Se kehitti uudenlaista "didaktista ajattelua ja käytäntöä". Luonnollisesti se ei voinut ratkaista kaikkia koulutuksen ongelmia. Mielenkiintoista on kuitenkin se, että didaktiikka oppiaineen sisällä kehittyi ongelmia ja jännitteitä, jotka vaativat menemään kurssiopetusta pitemmälle, tarkastelemaan oppimista laajempana kysymyksenä kuin uusien sisältöjen ja välineiden omaksumisena kurssilla. Koulutusohjelman ensimmäisessä vaiheessa ratkaisematta jääneet kysymykset on esitetty kuviossa 2.

Kuvio 2. Kognitiivisen kurssididaktiikan ja -suunnittelun ratkaisematta jääneet ongelmat

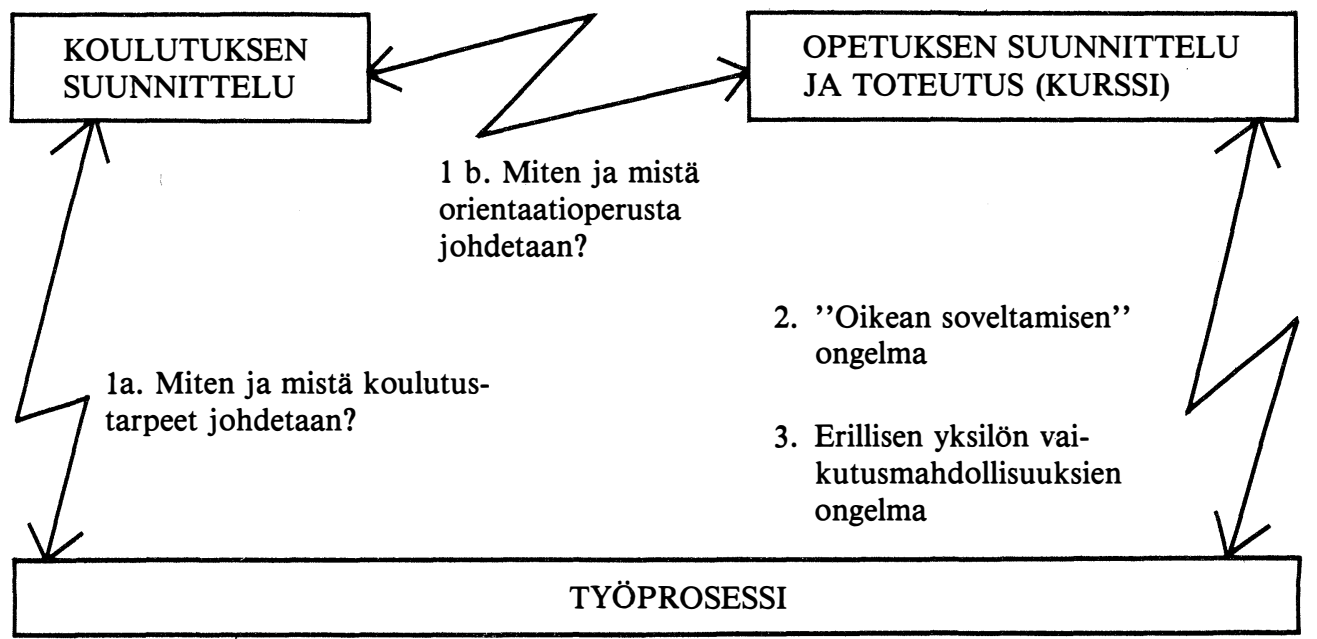

1. Edellisessä jaksossa jo todettiin, että kysymys koulutustarpeen määrittelyn menetelmästä ja tavasta oli jatkuvasti epäselvä. Koulutustarpeita yritettiin johtaa yhtä aikaisesti kolmesta erillisestä lähteestä: viraston toimintasuunnitelmat, organisaatioanalyysi ja ammattien analyysi. Tulos oli epätyydyttävä. Sama ongelma ilmeni koulutussuunnittelusta eriytyneessä didaktisessa l. koulutustilaisuuden tavoitteiden suunnittelussa. Kognitiivisessa kurssididaktiikassa noudatettiin sisällöllisen tavoitteenmäärittelyn ideaa: opetustavoite sisältää orientaatioperustan muodossa kiteytetyn kuvauksen siitä selitys- ja toimintamallista, johon perustuen tavoitteeksi asetettu uusi osaaminen voidaan saavuttaa.

Kuitenkin kysymys siitä, mistä ja miten orientaatioperusta johdetaan jäi erittäin puutteelliseen käsittelyn varaan. Lähinnä kursseilla tarjottiin jälleen kaksijakoista lähestymistapaa: analysoikaa työn ongelmia, solmukohtia sekä työn perustana olevien tieteiden ja teorioiden kehitystä. Tämän pitemmälle ei ollut mahdollista päästä ammattikeskeisestä työn käsitteestä käsin. Ongelma ilmeni voimakkaasti koettuna vaikeutena soveltaa orientaatioperustan ideaa muuten kuin jo olemassa olevan opetussisällön jäsentämisen välineenä. 
2. Toinen didaktiikkakursseilla esiin tullut ongelma oli oikean soveltamisen ongelma. Kursseilla korostettiin suuresti tiedon soveltamisen ja käytön merkitystä oppimistuloksen ja koulutuksen vaikuttavuuden kannalta. Kuitenkin kursseilla toteutettavat soveltamistehtävät jäävät keinotekoisina helposti harjoittelun tasolle eivätkö ne riitä turvaamaan tiedon käyttämistä ajattelun ja toiminnan kehittämisen välineenä käytännössä. Soveltaminen on oppimisen kannalta optimaalista, kun uusia välineitä edellyttävä tehtävä liittyy omaan työhön ja tuottaa todellisen hyödyllisen lopputuloksen. Tällainen tehtävä on kuitenkin samalla jo työn kehittämistä (muussa tapauksessa se ei ole "oikeaa" soveltamista). Tällaisen tiedon soveltamisen turvaaminen edellyttää oppimisen organisointia perinteisestä kurssimuodosta poikkeavalla tavalla, esim. kurssijaksojen ja työssä suoritettavien tehtävien vuorottelua. On huomattava, että oikean soveltamisen ongelmassa ei ole kyse vähemmästä kuin koulutuksen vaikuttavuudesta. Ellei tietoja pystytä itsenäisesti käyttämään ja soveltamaan, oppiminen ei vaikuta toisasialliseen työkäytäntöön tai paremminkin, oppiminen jää puolitiehen.

Koulutusohjelman käyneiden eräs keskeisimmistä johtopäätöksistä oli, että mielenkiintoiseksi ja haastavaksi koettuja opetussisältöjä ei ole kyetty soveltamaan omassa työssä. Tämä on epäilemättä ilmaus "oikean" soveltamisen ongelmasta itse koulutusohjelmassa.

3. Henkilöstökoulutuksen perinteinen ongelma on työyhteisöstään erillisen yksilön mahdollisuus soveltaa oppimaansa ja saada aikaan tosiasiallisia muutoksia organisaationsa työkäytännöissä. Jos yksi henkilö omaksuu uusia työprosessia koskevia käsityksiä ja välineitä, muut työyhteisössä eivät niitä voi omaksua (ja usein torjuvat ne): työkäytäntö ei muutu. Tätä ongelmaa organisaation kehittämisen (OD) perinne pyrki ratkaisemaan: miten saada kokonainen organisaatio oppimaan ja muuttamaan toimintatapaansa. Koulutusohjelmassa tämä ongelma ilmeni kurssilaisten epäuskoisuutena mahdollisuudesta yksin luoda uutta koulutuskäytäntöä organisaatioissa, joissa laaja lyhytkurssitoiminta on vakiintunut hallinnon toimintatavaksi. Koulutustoiminnan toteuttamiseen heidän organisaatioissaan osallistui suuri määrä eri asemissa olevia henkilöitä.

\section{Tietoisen oppimistoiminnan malli murtautuu ulos kurssimuodosta}

Vuosina 1981-1982 didaktiikka oppiaineen perustana oleva oppimiskäsitys kehittyi käsitteeksi tietoisesta oppimistoiminnasta. Tietorakenteiden psykologian painotus (oppiminen kognitiivisten rakenteiden muodostamisena ts. tiedon käsittelynä) korvautui kulttuurihistoriallisen toiminnan teorian käsityksellä oppimisesta toimintana. Tämän näkemyksen perustana on tämän koulukunnan useiden merkittävien edustajien työ. Tärkeä lähtökohta on L.S. Vygotskyn näkemys inhimillisestä toiminnasta välittyneenä toimintana ts. ihmisen suhde ulkoiseen todellisuuteen on historiallisesti kehittyvän kielen ja työvälineiden välittämää (Vy-

Kuvio 3. Tietoisen oppimistoiminnan malli

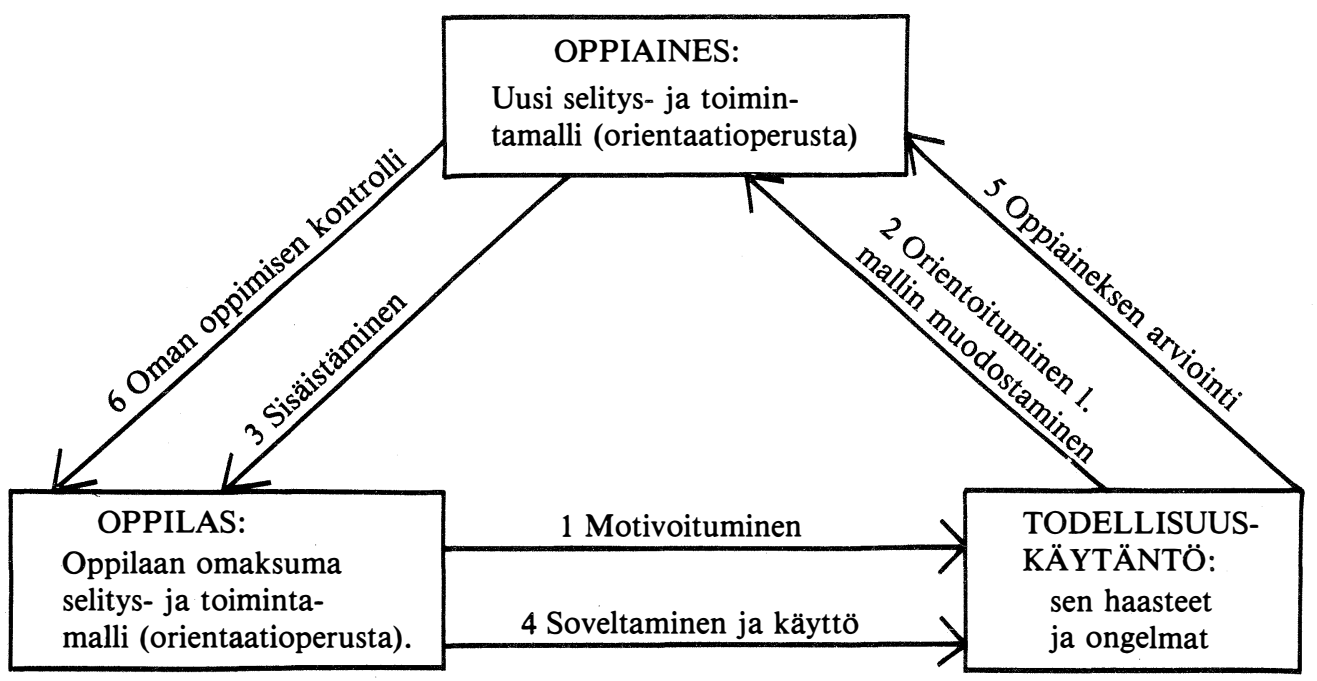


gotsky 1979). Keskeinen idea on toiminnan teorian varsinaisen muotoilijan A.N. Leontjevin näkemys siitä, että toiminnan määrittävä tekijä löytyy toimintaa ohjaavasta motiivista ts. siitä yhteiskunnallisesta tarkoituksesta, jota toiminta palvelee (Leontjev, 1977). Kolmas tärkeä teoreettinen perusta tietoisen oppimistoiminnan mallille on V.V. Davydovin teoria teoreettisten käsitteiden (tai mallien) muodostamisesța ja käytöstä oppimistoiminnan erityisenä välineenä. Yrjö Engeström muotoili näiden pohjalta vuonna 1981 tietoisen oppimistoiminnan kehämallin, joka on esitetty kuviossa 3 (Engeström 1981 ja 1984).

Tämä malli mullisti oppimis- ja didaktista ajattelua ensinnäkin sillä, että se nosti oppimisen mallin perustekijäksi luokkahuoneen ulkopuolisen todellisuuden ja käytännön. Työelämän aikuiskoulutuksessa tämä todellisuus on työtoiminta. Kognitiivisen kurssididaktiikan vaiheessa oppimisen malliksi nostettiin täydellinen oppimisprosessi, jonka tuli sisältää luettelona esitetyt osatekijät. Tämä malli oli eräänlainen "didaktinen normi', hyvän opetuksen yleinen lähtökohta. Tietoisen oppimistoiminnan malli murtaa tämän normatiivisuuden tuomalla malliin oppimisen kohteen, työtoiminnan, jonka kehittämiseksi ja hallitsemiseksi tiedot ja teoreettiset mallit ovat tarpeen. Luettelona esitettyjen oppimisprosessin osatekijöiden sijalle tulivat malliin sijoitetut oppimisteot. Tämän muutoksen merkitystä voidaan luonnehtia tarkastelemalla, miten kognitiivisen kurssididaktiikan peruskäsitteet kehittyivät tämän mallin pohjalta.

Sisällöllisen oppimismotivaation viriäminen (motivoituminen) on sijoitettu mallissa oppijan vallitsevan selitys- ja toimintamallin ja työtoiminnan väliin. Motivaation perusta ts. ovat ne työtoiminnan asettamat haasteet ja ongelmat, joiden ratkaisemiseksi nykyiset toimintamallit ja välineet eivät riitä. Sisällöllisen oppimismotivaation luomisessa tiedollisten ristiriitojen (aikaisempi tieto vs. uusi tieto) sijaan tulivat tiedollis-toiminnalliset ristiriidat. Tällaisen ristiriidan viriämisen prototyyppi on oppijan työhön liittyvä merkittävä tehtävä, josta hän ei suoriudu nykyisen ajattelu- ja toimintatapansa pohjalta.

Orientaatioperusta kehittyy oppiaineksen kiteyttävästä jäsennyksestä välineeksi ratkaista työn kehittämisen ongelmat, ts. työvälineeksi.

Orientaatioperustan sisältönä eivät ole enää tietyt tiedot tai peruskäsitteet sinänsä. Orientaatioperusta ymmärretään malliksi todellisesta, kehittyvästä kohteesta, jonkun työtoiminnan olennaisista kehitystekijöistä. Vasta kun tämä on hahmotettu, tulee ajatus erityyppisistä orientaatioperustoista ymmärrettäväksi. Teoreettiset mallit (alkusolutyyppinen) ovat tarpeen kehittyvän kokonaistoiminnan ymmärtämiseksi, yksittäisten työtehtävien suorittamisessa tarvitaan algoritmeja ja ennakkojäsentäjiä. Kun ne perustuvat kokonaiskohteen teoreettisen ymmärtämiseen, kyetään niitä itsenäisesti kehittämään ja muuttamaan.

Uusi käsitys oppimisprosessista heijastuu opetuksen suunnittelussa. Didaktinen kokonaiskäsittelyssä oppilaiden aktiivinen toiminta rajoittuu pääasiassa esittävää opetusta täydentäviin harjoitus- ja soveltamisjaksoihin. Tietoisen oppimistoiminnan mallissa jokainen oppimisteko on oppilaan aktiivista toimintaa. Siksi tämä toiminta pitäisi saada aikaan ja organisoida oppilastehtävien avulla. Opetus hahmotetaan oppilastehtävien sarjaksi.

Kun tarkastelee tietoisen oppimistoiminnan mallia, havaitsee sen avulla voitavan hahmottaa oppimisen lisäksi monia toimintoja. Eikö esimerkiksi suunnittelu ole prosessi, jossa toiminnan kohteesta pyritään muodostamaan mahdollisimman pätevä kokonaiskuva, toimitaan tämän käsityksen pohjalta ja toiminnan tulosten pohjalta tehdään johtopäätöksiä tulevaa toimintaa varten, täydennetään aikaisempaa kokonaiskäsitystä jne.? Tietoisen oppimistoiminnan mallin "ristiriitaisuus" onkin siinä, että se kuvaa itse asiassa osuvammin työtoiminnan kehittämistä teoreettisten mallien avulla kuin kurssioppimista. Oppimisen malli "kasvaa ulos"' kurssimuodosta ja vaatii toteutuakseen uudenlaisia organisaatiomuotoja. Engeström toteaakin tästä $(1984,108)$ : "...työtoiminnan puitteissa tapahtuva aikuisten oppimistoiminta edellyttää väistämättä itse työhön kohdistuvaa teoreettista tiedostamista ja käytännöllistä muovaamista, oppimistoiminnan muuntumista oppivaksi työtoiminnaksi."

\section{Muutos työn käsitteessä johtaa uudentyyppisen koulutuksen, kehittävän työntutkimuksen muodostumiseen}

Siirtymä ammattikeskeisestä työn käsitteestä työn hahmottamiseen kehittyvänä yhteiskunnallisena toimintajärjestelmänä oli ratkaiseva askel uuden koulutusnäkemyksen kehittymi- 
Kuvio 4. Työn yleinen malli

sessä. Vielä jatkokoulutusohjelman opetussuunnitelmassa ammatti oli työtieteen pääkäsite (s. 29):

"Työn ymmärtämiseksi on pääkäsitteeksi valittu "ammatti". Ammatti on yhteiskunnallisten työprosessien jakamisen ja niihin pätevöittämisen tärkein muoto. Ammatti on linkki yksilön ja yhteiskunnan välillä; se kytkeytyy ihmisen persoonallisuuteen eikä rajoitu organisaatioiden tarpeiden mukaan vaihteleviin erilaisiin työtehtäviin. Nykyaikaisen, tieteeseen perustuvan ammattipätevyyden oivaltaminen työn sisällöllisen ja organisatorisen kehittämisen mittapuuksi ja edellytykseksi on tämän tietoalueen solmukohta".

Ammatin käsite johtaa pyrkimykseen "institutionalisoida" ja vankalla teoreettisella koulutuksella vakiinnuttaa ja vahvistaa tiettyjen henkilöryhmien asemaa yhteiskunnallisen työnjaon puitteissa. Tämä pyrkimys johtaa monessa tapauksessa epätarkoituksenmukaisen työnjaon vakiintumiseen ja ehkäisee perinteisten tieteenala/oppiainejaot ylittävien monitieteisten lähestymistapojen muodostumista. Amerikkalainen Edgar Schein huomauttaakin, että professioammatin ihanteen mukaisesti "erityistietämystään" varjeleva ja asemaansa puolustava ammattikunta muodostuu yhä useammin uusien kehittyneempien työkäytäntöjen kehittämisen esteeksi. Näin tapahtuu Suomessa esim. sairaalalaitoksessa: asemastaan ja tehtävistään taistelevien ammattiryhmien edunharjoittaminen on sairaalalaitoksen toiminnan kehittämisen keskeinen este. Kun tavoitteena on kehittyneemmän työkäytännön ja uuden pätevyyden luominen, sekä vallitseva työnjako että vakiintuneet opinalat/työvälineet ovat kehittämisen (muuttamisen) kohteena. Siksi ne eivät voi olla kehittämisen lähtökohta ja perusta.

Kari Toikan kvalifikaation sosiologiaa koskevan työn perustalta (Toikka 1984) työn peruskäsitteeksi nostettiin ammatin sijaan työprosessi yhteiskunnallisena, kehittyvänä toimintajärjestelmänä. Jokaisessa työprosessissa on kolme vuorovaikutuksessa olevaa perustekijää: 1) työn subjekti (ts. työn suorittajat mukaanlukien työnjako ja organisaatio), 2) työvälineet (teoriat, menetelmät, laitteet) sekä 3) työn kohde ja työn tavoiteltu, hyödyllinen $t u$ los. Tämä työn yleinen malli on esitetty kuviossa 4.

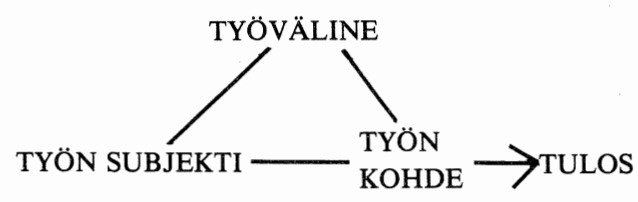

Jokainen työprosessin osatekijöistä kehittyy ja muuttuu ja näin syntyy jännitteitä ja ristiriitoja niiden välillä. Kerran luotu organisaatio ja työnjako ei ole tarkoituksenmukainen kokonaan uudenlaisten tulosten saavuttamiseksi. Vanha teoria ja työvälineet eivät riitä muuttuvan kohteen hallitsemiseksi jne. Näiden ristiriitojen kehitystä analysoimalla on mahdollista muodostaa käsitys siitä, mikä on työn seuraava mahdollinen kehitysvaihe eli lähikehityksen vyöhyke. Lähikehityksen vyöhyke sisältää ennakoivan kuvauksen, minkälaisen uuden työprosessin perustekijöiden uuden "kombinaation" avulla työn kehitysristiriidat ovat voitettavissa. Lähikehityksen vyöhyke sisältää siis myös hahmotelman uudesta tavoiteltavasta työnjaosta jo tarvittavista uusista työvälineistä.

Uusi työn käsite teki mahdolliseksi yrittää ratkaista kokonaan uudella tavalla ongelmat, joita kognitiivinen kurssididaktiikka ja sitä vastaava suunnittelu ei kyennyt ylittämään. Työn käsitteen merkitystä voidaan luonnehtia seuraavasti.

1) Se poisti erillisen koulutustarpeen arvioinnin ja opetuksen suunnittelun erillisyyden. Se liitti systeemiseksi kokonaisuudeksi ennen erillisinä lähtökohtina olleet organisaatio-, ammatti- ja oppiaines/tieteenala-analyysit ja suhteutti ne toisiinsa sekä työn kohteeseen ja tavoiteltavaan hyödylliseen lopputulokseen. Kaikki nämä ovat lähikehityksen vyöhykkeen osatekijöitä. Työtoiminnan analyysiin perustuva lähikehityksen vyöhyke ratkaisee kysymyksen, mistä ja miten koulutustarve olisi johdettava. Koulutuksessa tavoiteltava orientaatioperusta esiintyy tässä kokonaisuudessa välineenä lähikehityksen vyöhykkeen saavuttamiseksi.

2) Työn käsite synnytti myös uuden koulutuksen organisaatiomuodon, käytännöllisen tavan kehittää työtä ja siinä tarvittavaa pätevyyttä. Kehittävän työntutkimuksen (tai koulutuksen) mallissa työn tutkiminen ja analysointi ja lähikehityksen vyöhykkeen hahmottaminen (koulutustarpeen analysointi), uusien teoreettisten ja käytännöllisten välineiden muodostaminen (koulutusinterventio) sekä itse työn kehittäminen integroituvat yhtenäiseksi 
prosessiksi (vrt. kehittävän työntutkimuksen malli Yrjö Engeströmin artikkelissa tässä lehdessä). Tämä uusi koulutuksen ja työn kehittämisen organisaatiomuoto toteuttaa konkreettisesti oppimisen ja työtoiminnan toisiinsa liittämisen ja ratkaisee tällä tavoin "'oikean soveltamisen ongelman".

Uusi työn käsite oli tärkeä myös tietoisen oppimistoiminnan mallin ymmärtämisen ja kehkeytymisen kannalta ainakin kahdessa suhteessa.

3) Työn käsite vapautti oppimiskäsityksen intellektualismista, oppimisen tarkastelusta uuden tiedon ja aikaisemman tiedon välisenä suhteena. Työn käsite osoitti, että tieto on kehittyvä väline kehittyvän kohteen tiedostamiseksi ja hallitsemiseksi. Oppimistoiminnan kohteena on työprosessi. Työn käsite konkretisoi oppimisen kohteen ja teki sen ymmärrettäväksi. Se konkretisoi tiedon ja teorioiden riippuvuuden käytännöllisestä toiminnasta.

4) Työn käsite ratkaisi myös kognitiivisen kurssididaktiikan sisäisiä jännitteitä. Keskeinen kysymys oli esimerkiksi kysymys teoreettisistä käsitteistä ja -ajattelusta. Kognitiivisessa kurssididaktiikassa teoreettiset mallit ("alkusolutyyppiset" orientaatioperustat, yleiset periaatteet) esiintyivät yleisenä "didaktisena normina". Argumentaatio oli seuraava: tuloksekkaan oppimisen tärkein kriteeri on laaja sovellettavuus. Laajan sovellettavuuden turvaavat yleiset periaatteet ja teoreettiset käsitteet. Ajatuksen soveltaminen käytännössä, kurssien ja koulutuksen rakentamisessa, tuntui kuitenkin vaikealta. Toiminnan teorian näkökulma konkretisoi kysymystä oleellisesti. Teoreettisia malleja tarvitaan työn ymmärtämiseksi yhteiskunnallisena kokonaistoimintana, hyödyllisiä lopputuloksia tuottavana kokonaistoimintana. Uusi työn käsite (käsitys oppimisen kohteesta) teki tämän ymmärrettäväksi ja konkreettiseksi. Samalla tuli ymmärrettäväksi, että emme voi ymmärtää teoreettisesti yhteyksistään irroitettua työtehtävää tai tehtäväkokonaisuutta muuten kuin tarkastelemalla sitä osana kehittyvää, systeemistä työn kokonaisuutta. Siksi emme voi myöskään esittää yksittäisen tehtävän "teoreettista perustaa" tai yleistä periaatetta.

Edellä esitetty kehityskuvaus ei merkitse, että henkilöstökouluttajien jatkokoulutusohjelma olisi synnyttänyt kehittävän työn tutkimuksen tai ollut ratkaiseva sen muodostumiselle. Koulutusohjelman puitteissa tapahtunut oppimis- ja koulutusajattelun kehittyminen on yksi sen perusta. Sen muotoutuminen on tapahtunut toisaalta työtä ja pätevyyttä koske- van sosiologisen ja psykologisen tutkimuksen (kvalifikaatiotutkimuksen) piirissä. Tässä tutkimuksessa kävi ilmeiseksi, että työn ja työntekijöiden kehittämismahdollisuuksista on vaikea saada tietoa muuten kuin kytkemällä toisiinsa työn kehittämisehtojen tutkiminen ja itse työn kehittäminen koulutuksen avulla (Toikka 1984). Kehittävän työntutkimuksen ensimmäiset sovellutukset ovatkin toteutuneet tutkimustoiminnan piirissä. Esitetty analyysi osoittanee, että tämän tutkimusotteen perusajatukset tarjoavat merkittäviä mahdollisuuksia myös henkilöstökoulutuksen kehittämiselle. Sen käyttö edellyttää kuitenkin aidon ja kurinalaisen tutkimuksellisen otteen omaksumista henkilöstökoulutustyössä. Sen sovellutusyritykset henkilöstökoulutuksessa ovatkin vasta aivan alullaan.

\section{Henkilöstökouluttajien jatkokoulutusohjel- man kehittämisessä tuotetut julkaisut ilmesty- misjärjestyksessä}

Valtion henkilöstökouluttajien jatkokoulutusohjelman opetussuunnitelma. VKK:n julkaisusarja $B \mathrm{n}$ :o 12,1980

Engeström, Y. (1981a): Johdatusta didaktiikkaan.

VKK:n julkaisusarja B n:o 13.

Virkkunen, J. \& Miettinen, R. (1981): Opetus ja työstä oppiminen henkilöstön kehittämisessä. VKK:n julkaisusarja B n:o 14

Engeström, Y. (1981 b): Mielekăs oppiminen ja opetus. VKK:n julkaisusarja B n:o 17

Vartola, J. \& Toikka, K. \& Vihmalo, A. (1982): Kvalifikaatio ja työn vaatimukset koulutuksen suunnittelun lăhtőkohtana. VKK:n julkaisusarja B n:o 18

Engeström, Y. (1982): Perustietoa opetuksesta Valtiovarainministerio. Helsinki: Valtion painatuskeskus

Virkkunen, J. (1983): Ryhmäteoriat ja henkilosstökoulutus, yhteistyö opetuksen tavoitteena ja keinona. VKK:n julkaisusarja B n:o 22

Miettinen, R. (1984a): Kognitivisen oppimisnäkemyksen tausta. VKK:n julkaisusarja B n:o 24

Toikka, K. (1984): Kehittävä kvalifikaatiotutkimus. VKK:n julkaisusarja B n:o 25

Engeström, Y. (1984): Orientointi opetuksessa. VKK:n julkaisusarja B n:o 29

Miettinen, R. (1984 b): Henkilöstökouluttajan ammattikäytăntő ja sen tiedollinen perusta. VKK:n julkaisusarja n:o 31

Kognitiiviset ja kulttuurihistorialliset oppimisteoriat: didaktiikka I seminaarin esitelmiä vuosilta 1982-1984. VKK:n julkaisusarja B n:o 33

\section{Muut lähteet}

Ausubel, D. \& al. (1978): Educational psychology: A cognitive view. New York: Rinehart \& Winston.

Bruner, J. (1960): The process of education. New York: Wintage Books. 
Bruner, J. (1966): Toward a theory of instruction. Cambridge, Mass: Harvard University Press.

Launos, E. \& Peisa, S. (1979): Valtion henkilöstökouluttajien ammattikuvatutkimus. VKK:n julkaisusarja B n:o 6.
Leontjev, A.N. (1977): Toiminta, tietoisuus, persoonallisuus. Helsinki: Kansankulttuuri.

Vygotsky, L.S. (1978): Mind in society. Cambridge, Mass.: Harvard University Press. 